$5-1998$

\title{
Investigating Performance of Bonded Concrete Overlays
}

\author{
Norbert J. Delatte \\ Cleveland State University, n.delatte@csuohio.edu \\ David W. Fowler \\ University of Texas at Austin \\ B. Frank McCullough \\ University of Texas at Austin \\ Stefan F. Gräter \\ University of Texas at Austin
}

Follow this and additional works at: https://engagedscholarship.csuohio.edu/encee_facpub

Part of the Civil Engineering Commons, and the Structural Engineering Commons

How does access to this work benefit you? Let us know!

\section{Publisher's Statement}

(C) ASCE

\section{Original Citation}

Delatte, J., N., Fowler, D., McCullough, B., and Gräter, S. (1998). "Investigating Performance of Bonded Concrete Overlays." J.Perform.Constr.Facil., 12(2), 62-70.

This Article is brought to you for free and open access by the Civil and Environmental Engineering at EngagedScholarship@CSU. It has been accepted for inclusion in Civil and Environmental Engineering Faculty Publications by an authorized administrator of EngagedScholarship@CSU. For more information, please contact library.es@csuohio.edu. 


\title{
Investigating Performance of Bonded Concrete Overlays
}

\author{
By Norbert J. Delatte Jr., ${ }^{1}$ Member, ASCE, David W. Fowler, ${ }^{2}$ Fellow, ASCE, \\ B. Frank McCullough, ${ }^{3}$ Member, ASCE, and Stefan F. Gräter ${ }^{4}$
}

\begin{abstract}
A bonded concrete overlay (BCO) is a concrete pavement rehabilitation method used to extend the life of an existing concrete pavement. The BCO should bond fully with the existing concrete, leading to a thicker composite pavement section, a much stiffer pavement, and a considerable decrease in pavement stresses. For one project, cost estimates for a BCO were half as much as for full-depth replacement of a pavement. In some cases BCOs have delaminated shortly after construction. This paper proposes a framework for identifying the causes of early age delamination in BCOs. The early age behavior of newly constructed BCOs is examined. The factors affecting the long-term performance of the $\mathrm{BCO}$ are the quality of the surface preparation, the materials used in the $\mathrm{BCO}$, and the curing of the $\mathrm{BCO}$. Weather monitoring during $\mathrm{BCO}$ construction is recommended. Methods of detecting and mapping delaminations are discussed. Several BCO delamination case studies are analyzed using this framework. The model is useful not only for investigating BCO performance but also for understanding and preparing BCO construction specifications.
\end{abstract}

\section{INTRODUCTION}

A bonded concrete overlay $(\mathrm{BCO})$ is a concrete pavement rehabilitation method intended to add life to an existing concrete pavement. The design intent is for the $\mathrm{BCO}$ to bond fully with the existing concrete, leading to a thicker composite pavement section, a much stiffer pavement, and a considerable decrease in pavement stresses. Several states and countries have constructed BCOs, including Texas, California, Iowa, Missouri, Virginia, Louisiana, Canada, Belgium, and Japan (Neal 1983; Chanvillard et al. 1989; Verhoeven 1989; Teo et al. 1989; van Metzinger et al. 1991; King 1992; Delatte 1996; Whiting et al. 1993).

If bond is not achieved, then the increase in pavement stiffness will be much less, and the pavement structure may not perform as intended. In several instances, BCOs have failed to bond to base concrete. In some cases (Neal 1983; Verhoeven 1989; Lundy et al. 1991), newly constructed BCOs have had to be removed, at considerable cost and with substantial inconvenience to the traveling public. In other cases, expensive repairs have been necessary (Delatte et al. 1996).

Despite this difficulty, BCOs offer significant benefits over other pavement rehabilitation methods. At a relatively low cost, a substantial increase in the service life of a pavement can be obtained. For the El Paso project, cost estimates from two different contractors were $67-117 \%$ higher for full-depth replacement of a pavement than for a $\mathrm{BCO}$, for approximately equal quantities of work (Table 1). Furthermore, because it takes less time to construct an overlay than to replace the full depth of pavement, the lane closure time and inconvenience to the traveling public are greatly reduced.

In this paper, a framework for investigating the performance of BCOs is developed. The development of bond of BCOs is reviewed, to identify factors that lead to a higher risk of de- bonding. Four case studies of BCO debonding are analyzed, using the proposed framework.

In June 1995, as part of a research project for the Texas Department of Transportation (TxDOT), eight full-scale BCO test sections were cast on an aggregate haul road in El Paso, Tex. Bond breaker was used to induce partial delamination into each section. The intent was to compare different $\mathrm{BCO}$ designs and construction methods and to determine if delaminations could be detected by nondestructive methods, and if the delaminations would spread under environmental and traffic loading (Delatte 1996). The results of this test are examined as an additional case study, using the framework developed.

\section{BOND DEVELOPMENT}

At the interface between the BCO and the base slab, normal and shear stresses develop. Compressive normal stresses may be neglected. As the BCO contracts relative to the base slab due to shrinkage and temperature differentials, tensile and shear stresses develop. These stresses are highest at boundaries and corners (Fig. 1).

The bond at the interface between the $\mathrm{BCO}$ and the existing concrete resists these stresses. Interface bond consists of two components-interlock and adhesion. The effectiveness of interlock is determined by the roughness of the prepared surface. Adhesion is produced by development of chemical bonds between concrete paste and the cured substrate concrete (Mindess and Young 1981). Thus, adhesion is affected by the variables that normally affect paste-aggregate bond. For example, more porous aggregates will develop better adhesion (Mindess and Young 1981; Neville 1981).

Whereas adhesion develops as the concrete cures, the contribution of interlock does not change. However, improved surface roughness, in addition to improving interlock, also enhances adhesion. With a rougher surface, more area is available for the paste to adhere (Fig. 2). Interlock considerably increases the shear capacity of the interface bond.

For bond between paste and aggregate, Mindess and Young note that "the bond region is weak because cracks invariably exist at the paste-coarse aggregate interface, even in continuously moist-cured concrete and before the application of any external load" (Mindess and Young 1981). The same cracks, of course, will occur at the interface between the BCO paste and the base slab surface. These cracks are due to bleeding, segregation, and volume changes of cement and paste during setting and hydration (Mindess and Young 1981). In addition to the cracks caused by volume changes of the cement paste, cracks may also be expected to occur due to small differential movements between the $\mathrm{BCO}$ and the base slab. 
TABLE 1. Cost Estimate Comparison for BCO and Full-Depth Reconstruction (Delatte et al. 1996)

\begin{tabular}{|c|c|c|c|c|c|c|}
\hline \multirow[b]{2}{*}{$\begin{array}{c}\text { Pavement type } \\
\text { (1) }\end{array}$} & \multirow[b]{2}{*}{$\begin{array}{l}\text { Activity } \\
\text { (2) }\end{array}$} & \multirow[b]{2}{*}{$\begin{array}{l}\text { Quantity } \\
\text { (3) }\end{array}$} & \multicolumn{2}{|c|}{ Contractor 1} & \multicolumn{2}{|c|}{ Contractor 2} \\
\hline & & & $\begin{array}{l}\text { Price per } \\
\text { quantity } \\
\text { (dollars) } \\
\text { (4) }\end{array}$ & $\begin{array}{l}\text { Price per total } \\
\text { surface } \\
\text { (dollars) } \\
\text { (5) }\end{array}$ & $\begin{array}{c}\text { Price per } \\
\text { quantity } \\
\text { (dollars) } \\
\text { (6) }\end{array}$ & $\begin{array}{c}\text { Price per tota } \\
\text { surface } \\
\text { (dollars) } \\
(7)\end{array}$ \\
\hline $\begin{array}{l}\text { Overlay } \\
\text { [Total] } \\
\text { Full-depth reconstruction }\end{array}$ & $\begin{array}{l}165 \mathrm{~mm} \mathrm{BCO} \\
\text { Repair existing pavement } \\
330 \mathrm{~mm} \mathrm{CRCP} \\
\text { Terminal anchors } \\
\text { Hot mix base } \\
\text { Remove existing pavement }\end{array}$ & $\begin{array}{l}22,574 \mathrm{~m}^{2} \\
417 \mathrm{~m}^{2} \\
31,520 \mathrm{~m}^{2} \\
375 \mathrm{~m}^{3} \\
11,691 \text { tons } \\
31,520 \mathrm{~m}^{2} \\
\quad-\end{array}$ & $\begin{array}{c}37.20 \\
72.00 \\
- \\
59.64 \\
173.03 \\
42.90 \\
6.00 \\
-\end{array}$ & $\begin{array}{r}37.20 \\
1.33 \\
38.53 \\
59.64 \\
2.06 \\
15.91 \\
6.00 \\
83.61\end{array}$ & $\begin{array}{r}58.20 \\
216.00 \\
- \\
66.00 \\
232.93 \\
41.80 \\
10.80 \\
-\end{array}$ & $\begin{array}{r}58.20 \\
3.99 \\
56.79 \\
66.00 \\
2.77 \\
15.50 \\
10.80 \\
95.07\end{array}$ \\
\hline
\end{tabular}

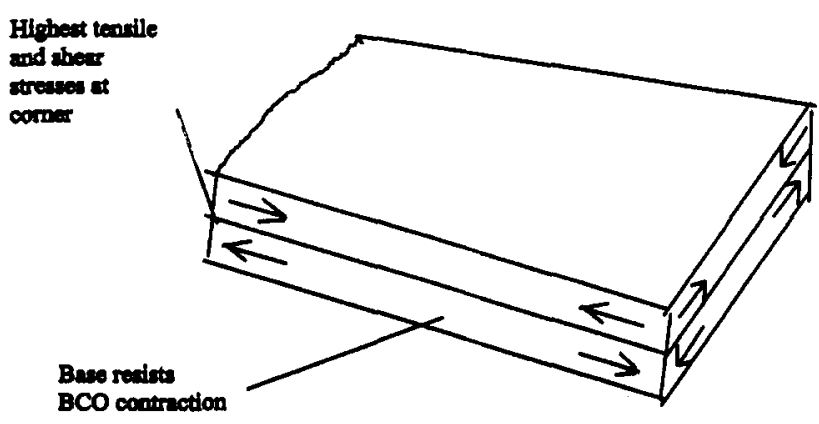

FIG. 1. Interface Stresese from BCO Contraction Relative to Base Slab

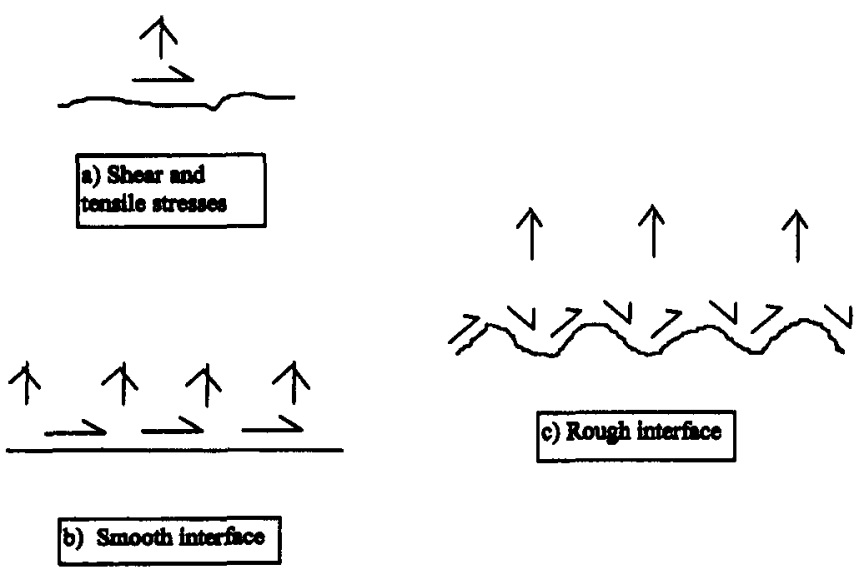

FIG. 2. Effect of Surface Roughness on Bond

\section{FACTORS AFFECTING PERFORMANCE}

Suprenant (1988) noted that concrete-to-concrete bond depends on surface preparation, selection and use of materials, and curing. All three must be present. Therefore, an inadequacy of one component (e.g., poor surface preparation) may lead to total loss of the bond. Each of these three may be envisioned as a link in a chain (Fig. 3). The chain is only as strong as its weakest link; thus, one failed component may lead to failure of the BCO system. Although this is a simple model, it may be helpful in gaining insight into poor performance of BCOs. Each component of the chain is addressed in the following sections.

\section{Surface Preparation}

The purpose of surface preparation is to enable the $\mathrm{BCO}$ to bond with the existing pavement. The surface preparation should leave the pavement clean and rough enough to provide both adhesion and interlock. It is also important that the surface preparation not damage the existing concrete below the

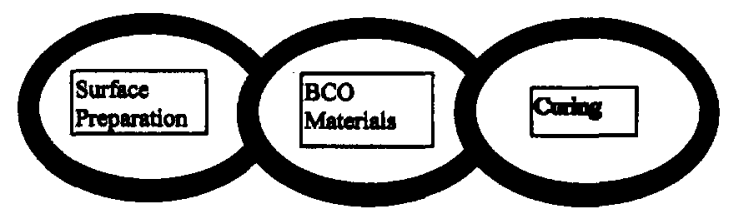

FIG. 3. Chain Model of Bond Strength

interface. Problems with bond will result if the prepared surface is not rough enough or becomes contaminated by dirt or debris. If the prepared surface is too dry and the concrete is of exceptionally low slump, the BCO concrete may lose moisture at the interface, leading to difficulties with bond.

\section{Methods}

The method selected should erode paste and expose clean aggregate, without damaging the existing concrete. Methods that have been used for surface preparation include steel shotblasting, cold milling, and sandblasting (McGhee 1994). The use of hydrocleaning was investigated as one of the full-scale test sections in El Paso (Delatte 1996). Cold milling should be avoided, because it may cause cracking below the prepared surface. Currently, steel shotblasting is the most commonly used method, although hydrocleaning appears to work as well.

\section{Standards}

Construction specifications must require a minimum level of roughness. The current TxDOT specifications require a 2.0 $\mathrm{mm}$ minimum average texture depth as measured by the Sand Patch Method and a clean, saturated surface dry pavement (Delatte et al. 1996). Different agencies have used different roughness criteria. Rougher textures lead to higher bond strengths (Whitney et al. 1992; Delatte 1996).

\section{Bonding Agents}

In the past, bonding agents such as grout or epoxy have been broomed or sprayed onto the existing pavement. Whitney et al. (1992) found that under most conditions bonding agents were not necessary. In fact, bonding agents may become bond breakers if they are allowed to cure before the BCO is placed.

\section{Shear Connectors}

Mechanical shear connectors have been used on several projects to provide additional safety against bond failure (Chanvillard et al. 1989; King 1992; Choi 1996). Shear connectors may decrease the likelihood or halt the spread of delamination.

\section{BCO Materials}

BCO materials should be selected and proportioned for rapid strength gain, minimum thermal expansion and contrac- 
TABLE 2. Recommended Curing for BCOs (Delatte et al. 1996)

\begin{tabular}{|c|c|}
\hline $\begin{array}{l}\text { Condition } \\
\text { (1) }\end{array}$ & $\begin{array}{l}\text { Recommendation } \\
\text { (2) }\end{array}$ \\
\hline 5 helore 0 & Membrane curing \\
\hline $\begin{array}{l}\text { Evaporation a } \\
\text { but below } 1\end{array}$ & $\begin{array}{l}\text { Membrane curing, plus evaporation } \\
\text { retardant or fogging or wet mats, } \\
\text { in place for } 12 \mathrm{~h}\end{array}$ \\
\hline Evaporation 0 & $\begin{array}{l}\text { Membrane curing, plus wet mat } \\
\text { curing or fogging or other meth- } \\
\text { ods approved by the engineer, in } \\
\text { place } 36 \mathrm{~h}\end{array}$ \\
\hline $\begin{array}{l}\text { Temperature drop in next } 24 \mathrm{~h} \\
\text { less than } 14^{\circ} \mathrm{C} \text { below tempera- } \\
\text { ture at time of paving }\end{array}$ & Membrane curing \\
\hline $\begin{array}{l}\text { Temperature drop in next } 24 \mathrm{~h} \\
\text { more than } 14^{\circ} \mathrm{C} \text { below tempera- } \\
\text { ture at time of paving }\end{array}$ & $\begin{array}{l}\text { Membrane curing plus wet mats for } \\
36 \mathrm{~h} \text {, or other methods as ap- } \\
\text { proved by the engineer }\end{array}$ \\
\hline
\end{tabular}

tion, and minimum shrinkage. Recommendations for materials are given in Delatte et al. (1996). Aggregates with high absorption or high thermal coefficients and concrete mixtures that generate high temperatures while hydrating should be avoided. The mix must have enough water for the paste to adhere to the base concrete.

\section{Curing}

Proper curing must be used to limit moisture loss and temperature gradients in the $\mathrm{BCO}$ to promote strength gain and limit thermal and shrinkage stress buildup. Many curing methods are available, including wet mats and membrane curing. Evaporation retardant may be used to enhance the effectiveness of these curing methods.

Curing methods and requirements depend on environmental conditions. TxDOT recommended special provisions for curing are summarized in Table 2 . If both evaporation over 0.5 $\mathrm{kg} / \mathrm{m}^{2} / \mathrm{h}$ and a temperature drop of $14^{\circ} \mathrm{C}$ or more are predicted, the most stringent curing (wet mats) should be used. Under marginal or severe conditions, a rougher pavement surface or shear connectors may also be used (Delatte et al. 1996). A portable weather station should be used to monitor environmental conditions. The data gathered may be used to determine when more stringent curing methods need to be used, or to investigate poor performance.

\section{DETECTING AND MAPPING DELAMINATIONS}

During and after construction of the eight full-scale test sections in El Paso, several electronic and nonelectronic nondestructive testing methods were used in an attempt to detect and

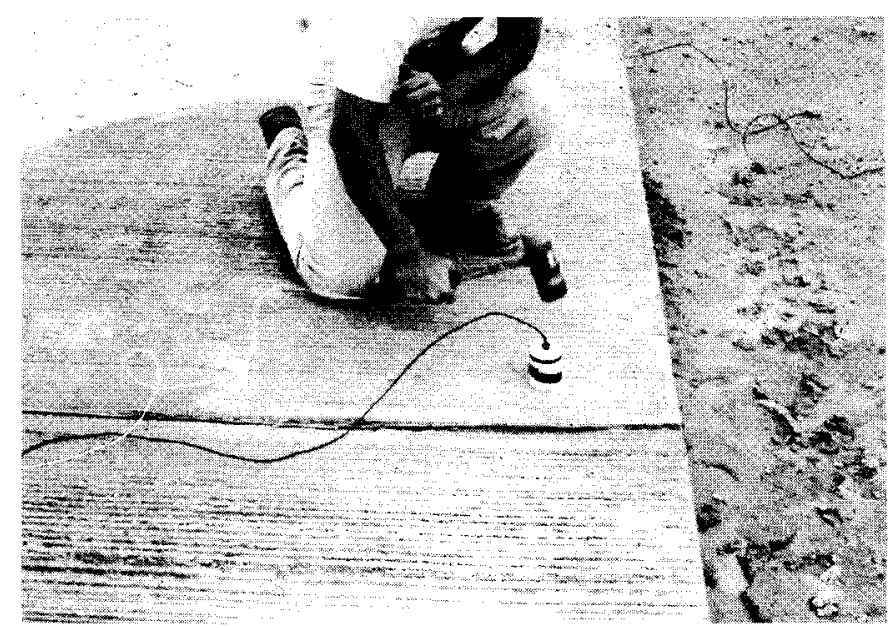

FIG. 4. Impulse-Response Testing map delaminations. The electronic methods were the spectral analysis of surface wave (SASW) method (Stokoe et al. 1988; Nazarian et al. 1988; Sheu et al. 1988), three different impactecho devices including the Defect Orientation Confirmation Tester (DOCter) (Sansalone and Carino 1988), impulse-response (Fig. 4), the Rolling Dynamic Deflectometer (RDD) (Fig. 5), and the Falling Weight Deflectometer (FWD) (Fig. 6).

Nonelectronic methods tested were rebar sounding and the impact (Schmidt) hammer. For rebar sounding, a piece of reinforcing steel 10 to $20 \mathrm{~mm}$ in diameter and 1 to $1.5 \mathrm{~m}$ long

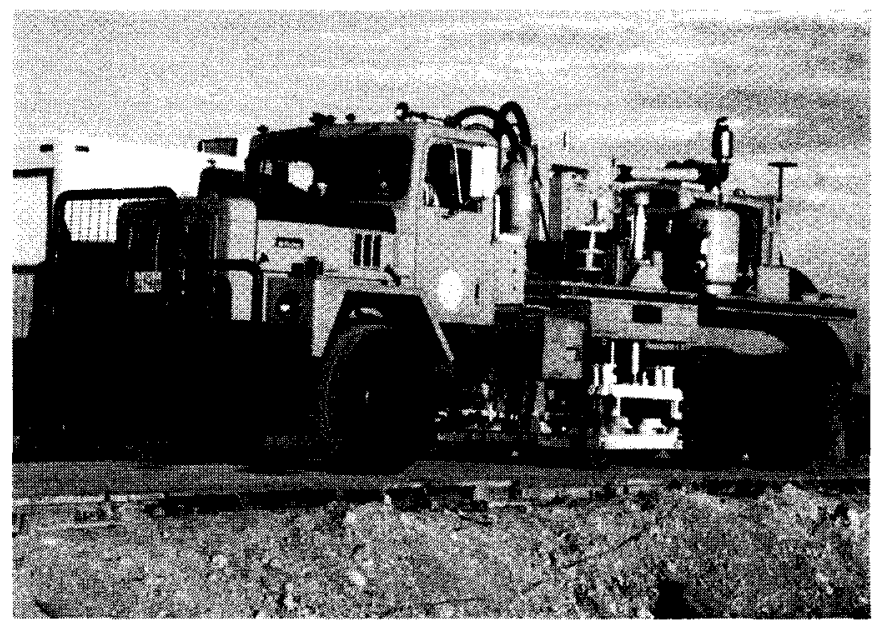

FIG. 5. Rolling Dynamic Deflectometer (RDD)

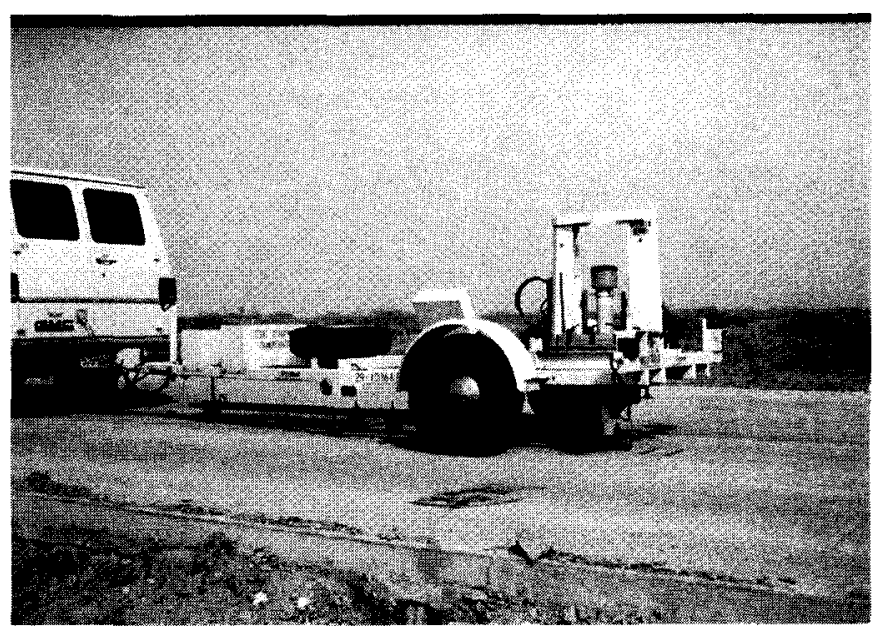

FIG. 6. Falling Weight Deflectometer (FWD)

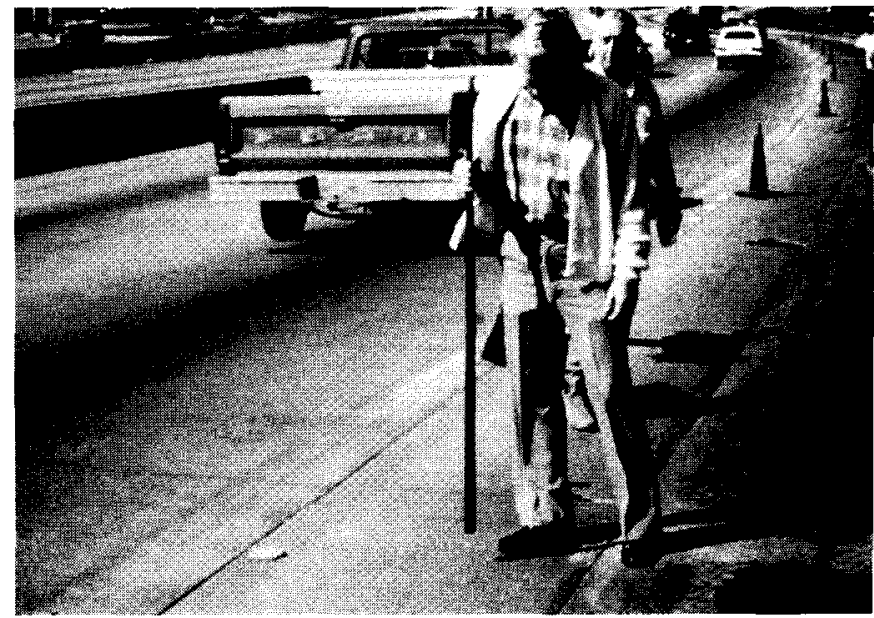

FIG. 7. Rebar Sounding 
is dropped on the overlay from a height of 100 to $300 \mathrm{~mm}$ (Fig. 7). Rebar dropped on the overlay over a delamination sounds "hollow" compared to a sounding made in the interior of the slab, where the BCO is presumably well bonded. Also, it is possible for the operator to feel vibrations in his feet when the rebar is dropped over a delamination. This method is subjective and dependent upon the skill of the operator. Cores were also drilled through the BCO to locate delaminations. The impact (Schmidt) hammer was unable to detect delaminations.

The most reliable method of detecting delaminations was coring, but coring is slow and expensive, and damages the pavement. Moreover, if the $\mathrm{BCO}$ has reinforcing steel, it is very difficult to avoid the steel. Cores that hit steel cannot be used to determine if the overlay was bonded, because the interface is damaged when the core barrel encounters the steel. Rebar sounding is useful, but is tedious and highly subjective. It is also less reliable with thicker overlays.

Of the other nondestructive testing methods used, SASW, impact-echo, and impulse-response all showed potential for detecting delaminations. The RDD as tested was not able to detect delaminations, although the equipment has since been modified (Stokoe and Bay, unpublished data, 1996). So far, the FWD has not been shown to be able to detect delaminations, either. Since it was difficult to attach the accelerometers needed for SASW or impact-echo to a tined pavement surface, impulse-response was much faster and easier and use.

In summary, electronic methods showed potential for locating delaminations, but could not sample large areas of pavement rapidly, with the current state of the art. Rebar sounding is still the easiest and fastest way to detect and map delaminations, despite the aforementioned limitations.

\section{CASE STUDIES}

When a BCO delaminates, the cause or causes may be found by considering the above factors. Was surface preparation inadequate? Were the materials used inappropriate for BCO construction? Was the BCO cured properly? Answering these questions provides insight into why the $\mathrm{BCO}$ failed.

\section{I-80 near Truckee, Calif., 1981 (Neal 1983)}

In 1981 a $2.4-\mathrm{km}$ section of a three-lane roadway was overlaid with a thin BCO on I-80 near Truckee, Calif. The existing pavement had been constructed in 1964, had been subjected to numerous freeze-thaw cycles, and had experienced considerable loss of wearing surface. It was 200 -mm-thick over 100 mm-thick cement treated base (CTB). The joints were skewed with staggered spacings. The roadway was considered structurally adequate, so the purpose of the $\mathrm{BCO}$ was to restore riding quality.

The test section was on a $5 \%$ grade at approximately 2,195 $\mathrm{m}$ of elevation. A 75-mm-thick overlay was selected. The surface of the existing concrete was sandblasted. Cold milling was used to remove rubberized asphalt and taper the transitions to the overlay. Large spalled areas were patched with fast-setting magnesium phosphate concrete. A neat cement grout was used as a bonding agent.

Paving of the first two lanes began June 25, 1981. Problems were encountered with excessive slump loss due to highly absorptive aggregate. The slump of the mix design was increased. The surface was hand floated, supplemented by bull floating, burlap dragged, and tined. A resin based curing compound was applied. Evaporation was high due to high temperatures $\left(27-30^{\circ} \mathrm{C}\right)$, low humidity $(10-15 \%)$ and high wind speeds (19-29 kph). Fogging was specified, but the wind made it less effective.

Guillotine shear tests performed on 100 -mm cores at 2 to 3 weeks indicated bond values of $2,400-3,800 \mathrm{kPa}$, which was considered adequate. Compressive strength tests of the core sections indicated 34.5-41.3 $\mathrm{MPa}$ for the $\mathrm{BCO}$ and 41.3-55.1 $\mathrm{MPa}$ for the original pavement.

Most of the overlay slabs were found to have transverse cracks at the pavement edges. Cracks were thin but numerous, with spacings as low as $0.3 \mathrm{~m}$. It was noted that cracking was probably due to volume change of the $\mathrm{BCO}$ at an early age, due to high evaporation rates (up to $1.5 \mathrm{~kg} / \mathrm{m}^{2} / \mathrm{h}$ ), the differential between fresh concrete and base concrete temperatures, a high temperature drop from day to night $\left(28^{\circ} \mathrm{C}\right.$ ambient temperature differential plus $22^{\circ} \mathrm{C}$ concrete surface temperature differential), high shrinkage concrete due to the highly absorptive aggregates used, and inadequate fogging. Cracking was not associated with the time of day, ambient temperature when the concrete was placed, wind direction, or pavement superelevation, cut, or fill.

After discovery of problems in the first two lanes, procedures were changed for constructing the third lane. The coarse aggregate stockpile was kept wet, and the pavement was fogged longer. No problems were encountered while paving the third lane, which was done in three days in July.

On Aug. 6 a core was taken near a crack and a joint in lane 2 and was found to be unbonded. Another core taken 3 in away had satisfactory bond $(2,800 \mathrm{kPa})$. Sounding with a hammer revealed extensive unbonded areas in this slab and throughout the section. All three lanes were surveyed for delamination between Aug. 11 and Sept. 22. Delamination in individual sections ranged from 5-88\%. During the survey, delamination progressed in some areas but not in others. To repair slabs, epoxy injection was attempted but was too time consuming to be satisfactory. The entire project was overlaid with asphalt concrete.

A thorough investigation of the bond failure was made. The grout may have dried before the overlay was placed in some areas, but where this had been observed, fresh grout had been sprayed on. Sandblasting may not have adequately prepared the existing pavement for the $\mathrm{BCO}$. In lanes where large amounts of aggregate had been exposed from surface attrition there was less delamination.

A laboratory testing program was undertaken to investigate delamination. Slabs 0.3 by $2.4 \mathrm{~m}$ by $75 \mathrm{~mm}$ thick were cast using the same materials that had been used on the project. Strain gages and thermocouples were installed. All tests ended in delamination. It was recommended that no thin bonded PCC overlays using cement grout be constructed in California until the debonding problem could be solved.

Applying the model discussed earlier to the BCO failure on I-80 in California, it appears that all three links of the chain were deficient. O'Neal noted that surface preparation may have been unsatisfactory, since the sandblasting used to prepare the surface may have not roughened it enough, and dried grout may have interfered with adhesion. The BCO concrete had high shrinkage due to highly absorptive aggregate. Finally, the curing did not adequately protect against moisture loss (since the fogging spray blew away) or protect against the $28^{\circ} \mathrm{C}$ temperature differential. Under these conditions, it is not surprising that the BCO delaminated.

\section{North Loop I-610, Houston, 1985 (Lundy et al. 1991)}

Following the successful performance of test sections constructed earlier on South Loop 610 in Houston, 10 sections were placed on North Loop 610. The existing pavement was 200-mm-thick CRCP. The variables considered in the study were overlay reinforcement and overlay aggregate. Eight sections were placed with welded wire fabric, and two with steel fiber reinforcement $\left(50 \mathrm{~kg} / \mathrm{m}^{3}\right.$ of concrete). The aggregates tested were siliceous river gravel and limestone. All overlay 
sections were $100 \mathrm{~mm}$ thick. The total length of the project was $5.1 \mathrm{~km}$.

Some delamination occurred, and condition surveys were taken in March and August of 1987 and in March of 1988. Delamination was detected and marked by sounding the overlay with a length of 19 or $25 \mathrm{~mm}$ (US \#6 or \#8) rebar, dropped onto the surface. This detection method was affected to some extent by the operator's hearing sensitivity. The cracks and delaminations were then logged using the automated road analyzer (ARAN).

Methods considered for detecting the delaminations were SASW, sounding, coring, and radar. Ultrasonic transmission and infrared thermography were considered but not tried because they did not seem promising given the conditions on I610 North Loop. Manual soundings with steel bars, hammers, or chains were made during the March 1987 and March 1988 condition surveys. SASW was used on an $0.74 \mathrm{~m}^{2}$ area during the March 1987 survey. Although the method was able to detect delaminations, it was very slow and labor intensive (4 man-hours for the small section investigated). Ground penetrating radar was tried in April 1988; data did not show any clear differences between delaminated and bonded areas. Only manual sounding was judged to be accurate and rapid enough for large-scale surveys. Overlays placed with limestone aggregate and WWF or siliceous river gravel (SRG) had less delamination than those placed with SRG and WWF (Lundy and McCullough 1989; Lundy et al. 1991). The reason was not clear, but may have been due to the higher thermal coefficient of SRG.

Attempts were made to repair the delaminated sections, but they were generally unsuccessful. Only two methods worked reasonably well. The first was monomer injection without water or compressed air flushing. The second was to sawcut and remove the overlay, then sandblast, then fill the gap with polymer concrete. The long-term success of these procedures was not verified.

Because a weather station was used to collect data during construction, it was possible to correlate delamination with evaporation rates. Delamination correlated well with higher evaporation rates $\left(0.7-1.0 \mathrm{~kg} / \mathrm{m}^{2} / \mathrm{h}\right)$. Delamination occurred where the temperature dropped more than $14^{\circ} \mathrm{C}$ between the time the concrete was placed and the next day. Using grout as a bonding agent gave higher bond strength than ungrouted sections, and ungrouted sections had a higher percentage of delamination. During subsequent investigation of the extent of the problem it was found that delamination was easier to detect in warm months. After delamination was detected, the percentage did not increase except for the ungrouted sections (Teo et al. 1989).

The observed delaminations were often detected within 24 $\mathrm{h}$ after overlay placement. In all cases where delamination occurred on I-610 South or North Loop it was located next to a joint or crack. The delaminations did not appear to be progressive over three years of observations. Analysis of cracking showed that cracks in the original pavement did not always reflect through, but pavement made with SRG had more cracking than that made with crushed limestone aggregate. Between surveys, transverse cracks increased in delaminated areas but not in nondelaminated areas. Analysis of both South and North Loop I-610 data led to the conclusion that reinforcing type, thickness, and aggregate are important to $\mathrm{BCO}$ transverse crack development and thus to interface stress development at early ages (van Metzinger et al. 1991).

Most debonding occurred at low stresses (less than $350 \mathrm{kPa}$ ) while the overlay was in an early curing stage. Bond was adequate under most conditions while the overlay was curing. Early debonding problems occurred only when environmental conditions caused significant combination of stresses at the interface at very early ages. Debonding also occurred when latex, used as a bonding agent, set prematurely. The latex then became a bond breaker.

Once the overlay had attained enough strength to be cored and tested, it had probably either developed enough strength or debonded. Consequently, the bond testing methods used only verified that the bond had formed. Several conditions were judged to adversely affect bond, including high substrate temperatures (over $52^{\circ} \mathrm{C}$ ), ambient temperature drops of more than $14^{\circ} \mathrm{C}$ during the $24-\mathrm{h}$ period immediately following the placement of the overlay, and evaporation rates exceeding 1.0 $\mathrm{kg} / \mathrm{m}^{2} / \mathrm{h}$. Under conditions where adverse environmental conditions cause a significant debonding risk, either epoxy bonding agent or severe shotblasting was recommended for use (Whitney et al. 1992).

The culprit for most of the delamination appeared to be inadequate curing and inability to control evaporation. Where the latex bonding agent was allowed to cure and become a bond breaker, surface preparation was at fault.

\section{Belgium (Verhoeven 1989)}

Twelve concrete overlays were constructed in Belgium, but only two were bonded to an existing concrete pavement. The other 10 were either placed over asphalt concrete or over portland cement concrete with an asphalt layer to prevent bond. All of the overlays were constructed at different sites.

The two bonded concrete overlays were constructed at Gent and Vierset. Surface preparations was either simple cleaning or milling, with and without grout. The overlays were constructed of SFRC with Bekaert Dramix fibers.

Results were poor. At Gent considerable debonding was observed, and the Vierset overlay exhibited considerable shrinkage cracking. It was suggested that had a proper bond been achieved, there would have been no advantage to using steel fibers. The grout did not appear to aid the bond, and it was noted that shotblasting would perhaps be a better surface preparation than milling; simple surface cleaning was clearly inadequate.

In this case, at least one cause of delamination was probable inadequate surface preparation.

\section{El Paso Full-Scale BCO Test Sections (Delatte ot al. 1996)}

As a preliminary step for preparing specifications for rehabilitating I-10, eight different designs for overlay test sections were constructed on an aggregate plant haul road in El Paso on June 22, 1995. On May 1, 1995, a continuously reinforced concrete pavement base slab $137.2 \mathrm{~m}$ in length was constructed to simulate the existing condition of $\mathrm{I}-10$. The pavement was $200 \mathrm{~mm}$ thick and $3.66 \mathrm{~m}$ wide. The original mix design was duplicated as closely as possible with the available cement and aggregates.

Over the next month before the $\mathrm{BCO}$ was cast, aggregate trucks were allowed to use the pavement in an attempt to induce fatigue damage. On June 22, 1995, a BCO one lane wide, $121.9 \mathrm{~m}$ long, and $165 \mathrm{~mm}$ thick was constructed. As stated previously, partial delaminations were built into the test sections. Observations were used to relate $B C O$ performance to surface preparation, BCO materials, and curing. A weather station collected temperature, humidity, and wind speed data.

For the eight full-scale BCO test sections, cores were drilled through the $\mathrm{BCO}$ into the base concrete to test the bond strength. A cap was epoxied on top of each core, and then the core was pulled off of the base concrete. The lowest bond strengths were found near wide cracks, where the highest differential movements between the $\mathrm{BCO}$ and base slab had occurred. In some sections, delaminations spread during the six 
months following construction of the test sections (Delatte 1996; Delatte et al. 1996).

Rougher surface preparation substantially improved performance of BCOs, for the range of roughnesses investigated. The rougher surface preparation of section 7 (mean roughness of $1.71 \mathrm{~mm}$, versus a mean roughness of $1.30 \mathrm{~mm}$ for the shotblasted sections) considerably reduced average crack width as well as delamination when compared to section 6 . The improvement occurred in spite of the fact that section 7 reached similar temperatures. Satisfactory bond was achieved without using any bonding agent.

Shear connectors in sections 4 and 5 functioned in a manner similar to rougher surface preparation in decreasing crack width and preventing delamination. The effect of shear connectors in preventing delamination did not seem to have been as great as that of rougher surface preparation. The delamination indicated by coring in section 5 (shear connectors) was similar to that in section 6 (no shear connectors), whereas no delamination was found in section 7 (rougher surface preparation, no shear connectors).

High performance concrete was shown to be an appropriate material for expedited BCO construction. BCO materials should be selected and proportioned for early strength development, minimum shrinkage, and minimum coefficient of thermal expansion. Concrete meeting the TxDOT DC overlay specification is appropriate for high early strength BCOs.

For hot and dry conditions, the best curing alternative is wet mats. Membrane curing is acceptable under less severe conditions. Under more severe conditions, night placement of the BCO may avoid excessive concrete heat buildup and evaporation.

The model may be used to explain the greater cracking and lower bond strengths observed in section 6 compared with sections 7 and 8. In all three sections the material (SFRC) was the same. However, the surface preparation in section 7 was superior due the greater roughness produced by the hydrocleaning equipment (a mean sand patch roughness of $1.71 \mathrm{~mm}$ versus $1.5 \mathrm{~mm}$ for shotblasting). Thus, the average crack width was narrower, and bond strengths were higher. Section 8 had better curing because it was cast in the evening. Thus, sections 7 and 8 illustrate the effects of superior surface preparation and curing on early age BCO behavior. In these sections, little spreading of the built-in delaminations was found

\section{I-10 El Paso (Delatte et al. 1996)}

Using the results from the full-scale test sections, specifications were written for rehabilitation of I-10. A $0.8 \mathrm{~km}$ section of overlay, $165 \mathrm{~mm}$ thick and 3.7-5.5 m wide, was placed on the inside lanes in both directions, over the original 200 $\mathrm{mm}$ thick continuously reinforced concrete pavement. The eastbound section was placed between June 25 and 30, 1996, while the westbound section was placed between July 17 and 22, 1996. Soon after construction, however, delaminations identified by coring confirmed that unexpected transverse cracking was due to a loss of bond. Continued coring and seismic testing identified the extent of the problem. Most of the delaminated sections are on the eastbound lanes, though

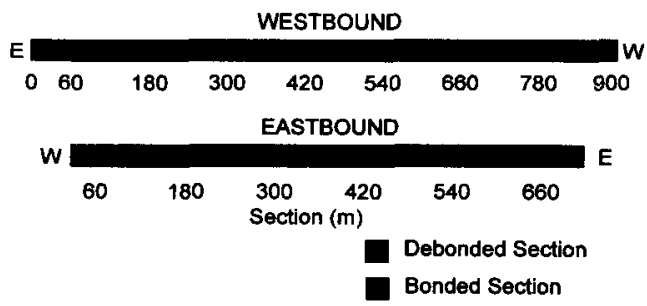

FIG. 8. Plan Vlew of BCO Showing Overlay Bonding Condition one westbound section was also delaminated. Fig. 8 shows a plan view of the project section, illustrating bonded and unbonded segments in both directions.

In order to find possible causes for the delamination, the weather station data gathered during the placement of the overlays were analyzed, as well as the concrete mix moisture content. Ambient temperatures and water evaporation rates were studied for the periods that concrete was placed. Information was provided by correlating the time of placement and the section placed. Figs. 9 and 10 present the average temperatures during the construction period for the eastbound and westbound lanes, respectively. The most critical temperatures occurred while the westbound lanes were overlaid, especially the 240-400 m section, which includes the only unbonded section in that direction, where the average temperature was $33^{\circ} \mathrm{C}$. In the eastbound direction, the temperatures were not as high, but the two sections with highest temperature recordings (between 600 and $700 \mathrm{~m}$ ) had unbonded segments.

Figs. 11 and 12 show the average evaporation rates during overlay placement for the eastbound and westbound lanes, respectively. Water evaporation rate from freshly placed concrete is a function of the wind speed, air and concrete temperatures, and relative humidity. Evaporation rates of $1 \mathrm{~kg} / \mathrm{m}^{2} / \mathrm{h}$ or greater are considered critical during overlay placement. In this case, none of the average values surpassed that standard, but there were higher evaporation rates associated with delaminated areas. The highest evaporation rate $\left(0.88 \mathrm{~kg} / \mathrm{m}^{2} / \mathrm{h}\right)$ occurred on the 600-660 m westbound section, which includes the unbonded part of the overlay.

Evaporation rates, in combination with the time elapsed between the overlay placement and the application of the curing compound, may have been a cause of the delamination. A mix

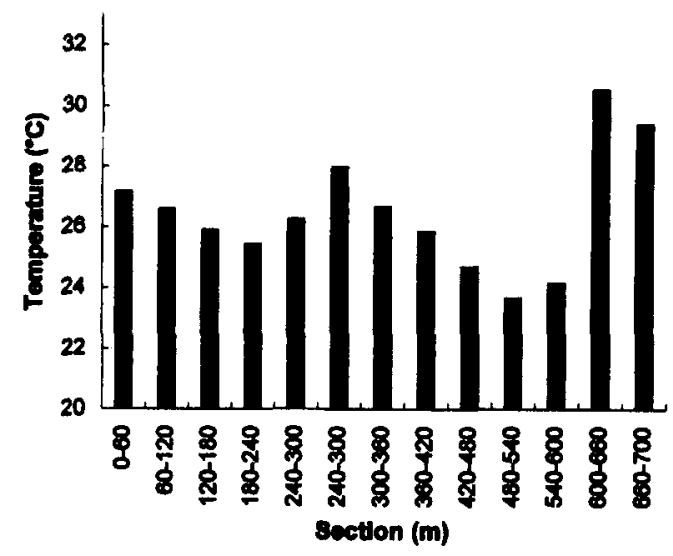

FIG. 9. Average Ambient Temperatures during Eastbound Lane Construction

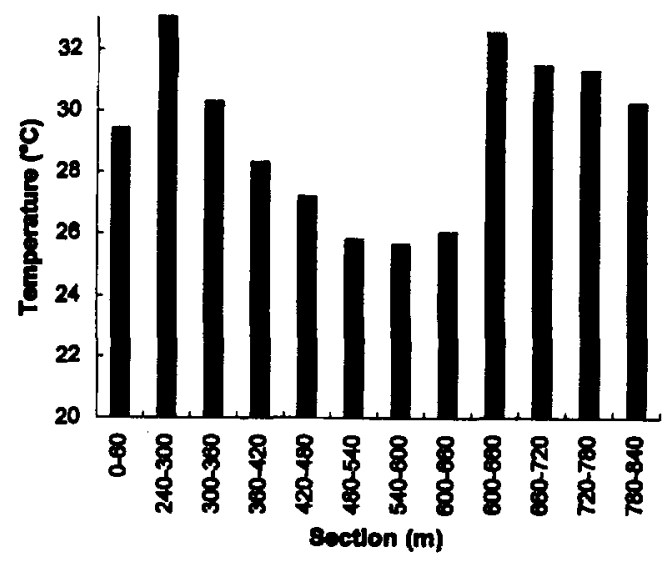

FIG. 10. Average Amblent Temperatures during Westbound Lane Construction 


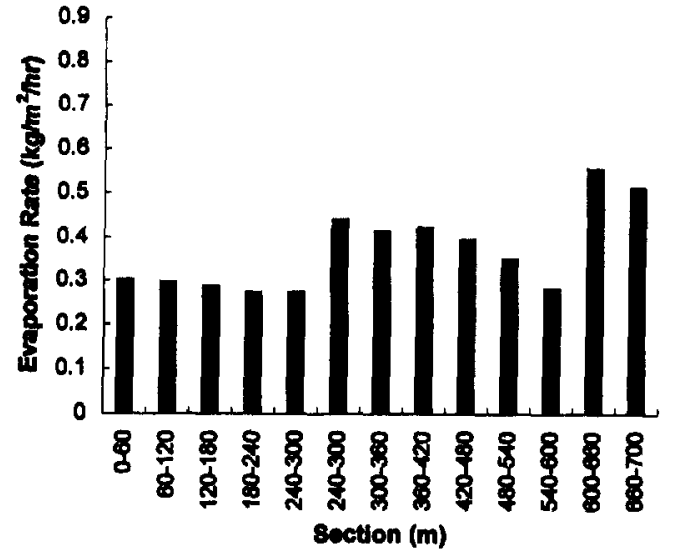

FIG. 11. Average Evaporation Rates during Eastbound Lane Construction

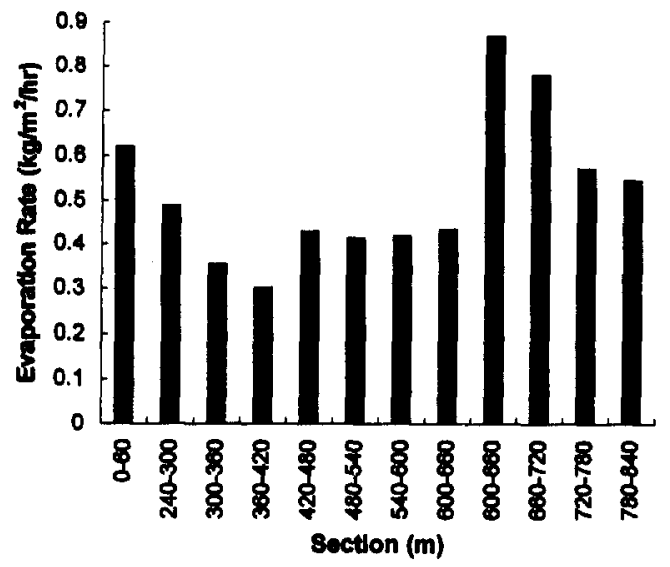

FIG. 12. Average Evaporation Rates during Westbound Lane Construction

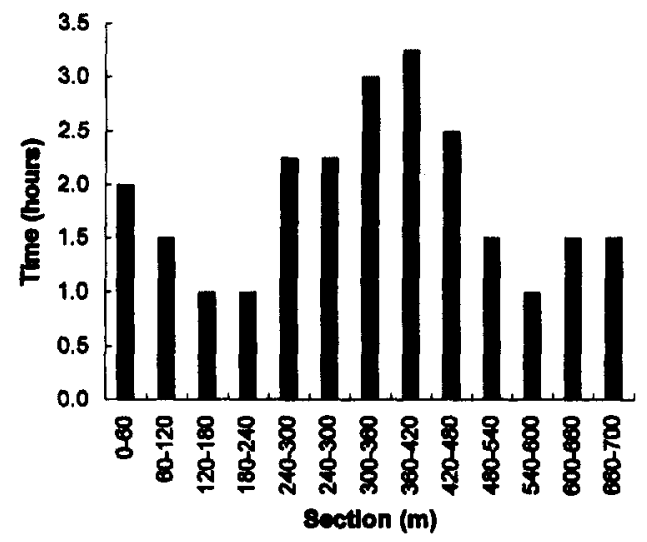

FIG. 13. Time between Concrete Placement and Application of Curing Compound on Eastbound Lane

that was dry to start with in order to satisfy the strength requirement may have lost critical water required for adequate adhesion. Figs. 13 and 14 illustrate the time after overlay construction until curing, for the eastbound and westbound lanes, respectively. In some cases, the surface of the overlay for the eastbound lanes lost moisture for about three hours before the curing process started. Limiting water loss to evaporation is an important construction aspect that should be carefully followed up to avoid delaminations in the future.

Water losses that occurred after the overlay was placed and before the curing compound was sprayed on are illustrated in Figs. 15 and 16. The mix design called for a water content of $138 \mathrm{~kg} / \mathrm{m}^{3}$. The water content indicated in the figures as "target" is the water content for the mix after corrections for ag- gregate moisture content were made. An additional adjustment to the design water content was made by withholding water at the batch plant. The withheld water content varied from 13 $\mathrm{kg} / \mathrm{m}^{3}$ on the eastbound lane and $2 \mathrm{~kg} / \mathrm{m}^{3}$ on the westbound lane. The line in figures indicated by the legend "before curing" was calculated by subtracting the water withheld and the water that evaporated from the pavement before curing compound was applied, from the target value. The difference between the "target" and "before curing" water contents in the figures, therefore, indicate the amount of water absent from the mix at the time of curing as was specified by the mix design. This water deficiency resulted in a stiff mix that was not workable and had low adhesion.

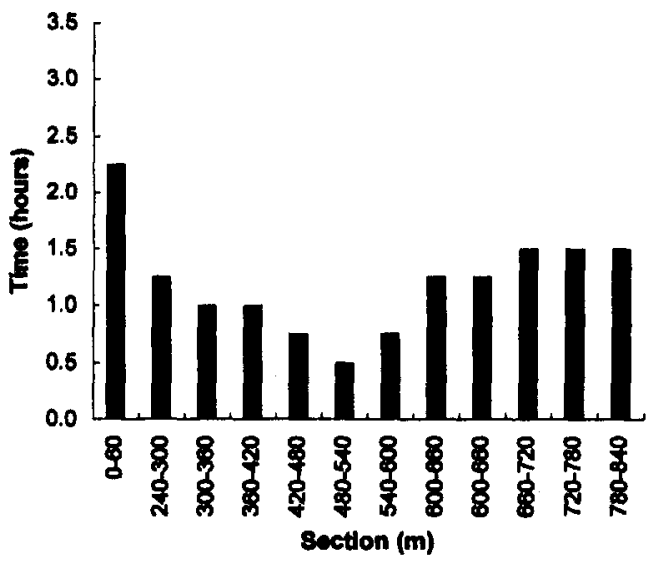

FIG. 14. Time between Concrete Placement and Application of Curing Compound on Westbound Lane

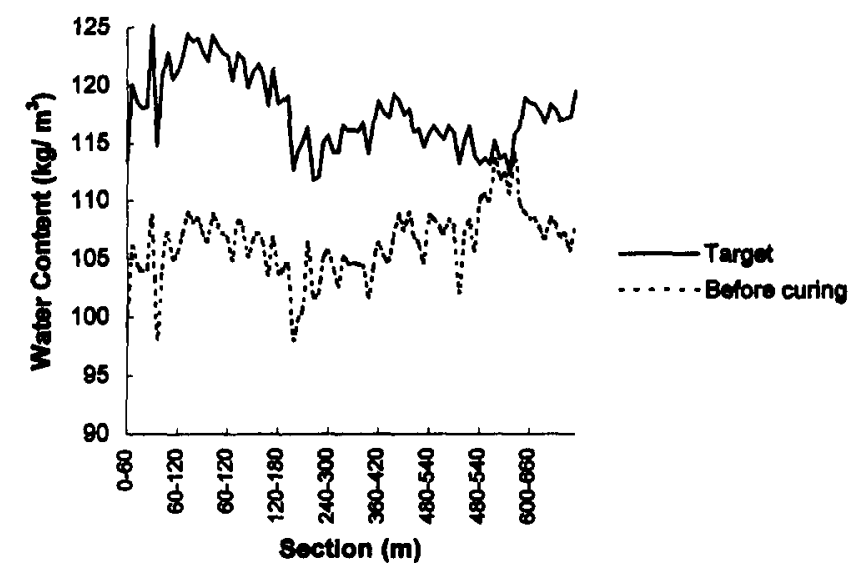

FIG. 15. Design Water Content, Corrected for Aggregate Moleture Content (Target) and Actual Water Content at Time of Curing Compound Placement (before Curing) for Eastbound Lane

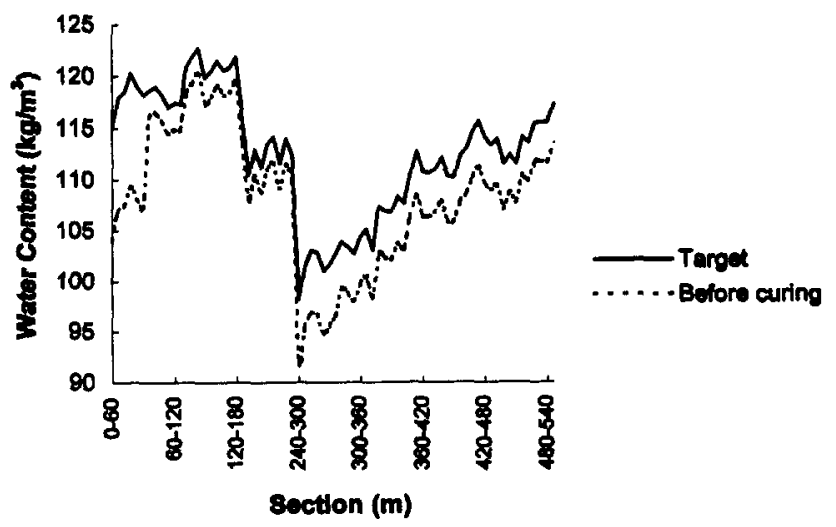

FIG. 16. Design Water Content, Corrected for Aggregate Molsture Content (Target) and Actuai Water Content at Time of Curing Compound Placement (before Curing) for Westbound Lane 
Deflections on the pavement were measured with falling weight deflectometer (FWD) and included sections of 330mm-thick CRCP that are adjacent to the BCO. Deflections on the eastbound lane were significantly higher on the unbonded, overlaid sections than on the adjacent, new, full-depth CRCP sections.

The data presented imply that the delamination of the overlay was due mainly to inadequate paste adhesion caused by deficiencies in surface preparation, materials, and curing. The loss in adhesion was caused by the low initial water content of the concrete mix compounded by the loss of available water to evaporation and by adsorption into the dry existing pavement, and to the action of withholding water from the mix at batching.

The prepared surface was significantly drier than that of the eight test sections analyzed in the earlier case study. Furthermore, it may have been contaminated with dust or debris before the BCO was placed. The full-scale test sections had been pressure washed the afternoon before paving; thus, the surface was clean and saturated surface dry.

Since the placed overlay mix contained a water content at the minimum required for hydration and adhesion, any loss of water increased the likelihood of low bond strength and the occurrence of delamination. The effect of surface preparation, was, therefore, critical since dust and debris on the surface or a very dry surface will have soaked up water from the mix, decreasing adhesion strength. To ensure appropriate water content of the concrete mix for future placements, the water-cement ratio should be increased, even if the change implies giving up concrete strength. The concrete used was probably unusually sensitive to inadequate curing.

Curing was probably not adequate, due to delayed application of curing compounds. Placing the curing compound as soon as possible will prevent water losses due to evaporation. Withholding water at the time of batching is strongly discouraged when concrete mixes with low water to cement ratios are used. This final case study indicates that the Falling Weight Deflectometer may be used to detect and map widespread delaminations, if not the smaller local ones built in to the test sections.

\section{SUMMARY AND CONCLUSIONS}

A BCO is a cost-effective and efficient method for rehabilitation of a concrete pavement, as shown in Table 1 (Delatte et al. 1996). However, the risks of delamination have made some agencies reluctant to use them. Repairs may be costly and difficult to perform and evaluate. Therefore, it is important to understand the conditions that lead to poor BCO performance, and avoid those conditions.

The investigative framework presented here allows an understanding of why delaminations have occurred in the past, and how they may be prevented in the future. Delaminations may occur due to deficiencies in surface preparation, materials selection or proportioning, or curing. When delaminations occur, they may be difficult to detect and map, particularly with thicker overlays. Rebar sounding is currently the best available method for delamination detection and mapping, although if large areas of the BCO are delaminated, the RDD or FWD might also indicate them. Weather station monitoring, as was used in Houston and the El Paso experiment and case study, is also recommended.

When properly designed and constructed, the cost of a BCO is approximately half that of full depth reconstruction, as shown in Table 1. Even with the costly epoxy repair at El Paso, the cost per square meter of the BCO was still less than that of the full-depth reconstruction. By following the recommendations listed in Table 2 and discussed in Delatte et al.
(1996), it is possible to construct economical and reliable BCOs.

\section{ACKNOWLEDGMENTS}

The Texas Department of Transportation sponsored this research. Technical expertise provided by TxDOT's El Paso District was essential to the success of this study. The assistance of Ned Finney and Stanley Jobe of Jobe Concrete Products and the Dan Williams Construction Company in constructing the test sections, as well as providing important suggestions on mix design and construction procedures, is gratefully acknowledged. Valuable support was also provided by The Hilti Corporation, Brent Rauhut Engineering, Olson Engineering, Rio Grande Cement, Master Builders Technologies, Monex Resources, W. R. Grace, NOVOCON, Bekaert Corporation, Forta Corporation, Humble Equipment Company, Nelson Industrial Services, Inc., the Rampart Division of Flow International, and Construction Technologies Laboratories. Thanks are due to Jeff Huddleston, Scott Williamson, Dong Uk Choi, Dawn Wade, Jim Bay, Axel Novion, Jung Hoon Choi, Brett Bystrom, and Nathan Jurgens for their assistance in preparing for and performing this test.

\section{APPENDIX. REFERENCES}

Chanvillard, G., Aitcin, P. C., and Lupien, C. (1989). "Thin concrete overlay with steel-fibre-reinforced concrete." Paper No. 880666, 68th Annual Meeting, Transportation Research Board, Washington, D.C.

Choi, D. U. (1996). "An experimental investigation of interface bond strength of concrete using large powder-driven nails," $\mathrm{PhD}$ dissertation, University of Texas at Austin, Austin, Tex

Delatte, N. J. (1996). "High early strength bonded concrete overlay designs and construction methods for rehabilitation of CRCP." PhD dissertation, University of Texas at Austin, Austin, Tex.

Delatte, N. J., Gräter, S. F., Treviño-Frias, M., Fowler, D. W., and McCullough, B. F. (1996). "Partial construction report of a bonded concrete overlay on IH-10, El Paso and guide for expedited bonded concrete overlay design and construction." Rep. 2911-5F, Center for Transportation Research, University of Texas at Austin, Austin. Tex.

King, W. M. (1992). "Design and construction of a bonded fiber concrete overlay of CRCP (Louisiana, Interstate Route 10, August 1990)." Rep. No. FHWA/LA-92/266, Louisiana Transportation Research Center, Baton Rouge, La

Lundy, J. R., and McCullough, B. F. (1989). "Delamination in bonded concrete overlays of continuously reinforced pavement." Proc., 4 th Int. Conf. of Concrete Pavement Des. and Rehabilitation, Purdue Univ., West Lafayette, Ind., 221-229.

Lundy, J. R., McCullough, B. F., and Fowler, D. W. (1991). "Delamination of bonded concrete overlays at early ages." Rep. 1205-2, Center for Transportation Research, University of Texas at Austin, Austin, Tex.

McGhee, K. H. (1994). Portland cement concrete resurfacing. Synthesis of Highway Practice 204, National Cooperative Highway Research Program, Washington, D.C.

Mindess, S., and Young, J. F. (1981). Concrete. Prentice-Hall, Inc., Edgewood Cliffs, N.J.

Nazarian, S., Stokoe, K. H. II, Briggs, R. C., and Rogers, R. (1988). "Determination of pavement layer thicknesses and moduli by SASW method." Pavement Evaluation and Rehabilitation. Transportation Research Record 1196, Transportation Research Board, Washington, D.C., $133-150$.

Neal, B. F. (1983). "California's Thin Bonded PCC Overlay." Rep. No. FHWA/CA/TL-83-04, Sacramento, Calif.

Neville, A. M. (1981). Properties of concrete. 3rd Ed., Pitman Publishing, Inc., Marshfield, Mass.

Sansalone, M., and Carino, N. J. (1988). "Impact-Echo Method." Concrete Int., 10(4)

Sheu, J. C., Stokoe, K. H. II, and Roesset, J. M. (1988). "Effect of reflected waves in SASW testing of pavements." Pavement Evaluation and Rehabilitation, Transportation Research Record 1196, Transportation Research Board, Washington, D.C., 51-61.

Stokoe, K. H., Nazerian, S., Rix, G. J., Sanchez-Salinero, I., Sheu, J.-C., and Mok, Y.,-J. (1988). "In situ seismic testing of hard-to-sample soils by surface wave method." Proc., Specialty Conf. on Earthquake Engrg. and Soil Dynamics II-Recent Advances in Ground Motion Evaluation, ASCE.

Suprenant, B. (1988). "Bonding new concrete to old." Concrete Constr., $33(7), 676-680$.

Teo, K. J., Fowler, D. W., and McCullough, B. F. (1989). “Monitoring and testing of the bonded concrete overlay on Interstate Highway 610 North in Houston, Texas." Res. Rep. 920-3. Center for Transportation Research, University of Texas at Austin, Austin, Tex. 
van Metzinger, W. A., Lundy, J. R., McCullough, B. F., and Fowler, D. W. (1991). "Design and construction of bonded concrete overlays." Res. Rep. 1205-4F, Center for Transportation Research, University of Texas at Austin, Austin, Tex.

Verhoeven, K. (1989). "Thin overlays of steel fiber reinforced concrete and continuously reinforced concrete, state of the art in Belgium.'

Proc., 4th Int. Conf. of Concrete Pavement Des. and Rehabilitation,

Purdue Univ., West Lafayette, Ind., 205-219.
Whiting, D., Todres, A., Nagi, M., Yu, T., Peshkin, D., Darter, M., Holm, J., Andersen, M., and Geiker, M. (1993). "Synthesis of current and projected concrete highway technology." SHRP-C-345, Strategic Highway Research Program, National Research Council, Washington, D.C Whitney, D. P., Isis, P., McCullough, B. F., and Fowler, D. W. (1992) "An investigation of various factors affecting bond in bonded concrete overlays." Res. Rep. 920-5, Center for Transportation Research, University of Texas at Austin, Austin, Tex. 